\title{
Effect of fertilizer on productivity of legume-cereal grass mixture
}

Olifirovich V. ${ }^{1}$, Osadchuk V. ${ }^{2}$, Osadchuk D. ${ }^{3}$, Makoviychuk S. $^{4}$

Bukovyna state agricultural experimental station of NAAS, Kryzhanovskyi Bogdan Street, 21 a, Chernivtsi, 58026, Ukraine; e-mail: ${ }^{1-4}$ buksaes@meta.ua

The purpose. To study effect of fertilizers on dynamics of harvesting dry matter and feeding capacity of grass mixture of lotus and timothy. Methods. Field and laboratory researches. Results. Results of researches of influence of bacterial preparation Rizobofit, phosphoric and molybdenum fertilizers on dynamics of harvesting dry matter for the first 3 years of use of legume-cereal grass stand are brought. Increment of dry matter from application of Rizobofit makes 3,5\%, at joint application of biological product on the background of phosphate fertilizer (P60) - 18,6\%. High efficiency of Rizobofit was observed in the 1-st hay cutting of the first 2 years of use of the grass stand. Combination of treatment of seeds with Rizobofit and ammonium molybdate was inefficient, and was followed by decrease of exit of dry matter. They also determined influence of ways of fertilizing upon feeding capacity of perennial agrophytocenosis. So, on the average for the first 3 years of use of perennial grasses the least productive was legume-cereal grass stand without use of fertilizers where exit of dry matter had made $6,88 \mathrm{t} /$ hectare, feed units $-5,26 \mathrm{t} /$ hectare, crude protein $-0,91 \mathrm{t} /$ hectare. Use of fertilizers essentially raised carrying capacity of grass mixture of lotus with timothy. So, inoculation of seeds of lotus with Rizobofit promoted increase in exit of dry matter for $0,24 \mathrm{t} /$ hectare, or $3,5 \%$, feed units - for $0,26 \mathrm{t} /$ hectare, or $4,9 \%$, crude protein - for $0,15 \mathrm{t} /$ hectare, or $16,5 \%$. So, in their researches use of Rizobofit had more influenced exit of crude protein for 1 hectare. Application of biological product Rizobofit on the background of phosphate fertilizers (P60) provided increase in exit of dry matter (in relation to grass stand without fertilizers) on 1,28 t/hectare, or 19,7\%; feed units - on $0,99 \mathrm{t} /$ hectare, or $18,8 \%$; crude protein - on $0,32 \mathrm{t} /$ hectare, or $35,2 \%$. Conclusions. Entering of phosphate fertilizers into combination to inoculation of seeds of lotus with Rizobofit promoted formation of the maximum feed capacity of legume-cereal grass stand. Use of Rizofobit plays an important role in increase of gathering crude protein. So, at joint application of biological product and phosphoric fertilizer $\left(P_{60}\right)$ the output of crude protein for 1 hectare has increased for $35,2 \%$ in comparison with a variant without fertilizer.

Key words: productivity, lotus, timothy, fertilizers, inoculation.

https://doi.org/10.31073/agrovisnyk201811-07

On slopes, the perennial herbs productivity is mostly limited by nutrients presence in soil. That is why, for obtaining high yields of perennial herbs, systematic fertilization is necessary [1]. Due to symbiotic nitrogen fixation, perennial legume fodder grasses have a great potential for reducing the need for industrial nitrogen fertilizers [2]. Symbiotic nitrogen is one of the basic sources of nutrition on perennial fodder lands with legume grasses [3]. Nitrogen biologic fixation with perennial legume grasses in mixed herbages depend on three basic factors: legume components preservation; soil provision with nitrogen; competitive relationship in herbages. Among these factors, there is a constant interaction [4]. A part of biologic nitrogen in forming the yield of bird's-foot trefoil may be $70-80 \%$ [5]. That is why the nitrogen fixation process strengthening, which is carried out in symbiosis process with tuberous bacteria - is the most important reserve of increasing the perennial legume grasses productivity [6].

One of the modes of symbiosis functioning conditions optimization is the implementation of seed inoculation [7]. Pre-sowing seed inoculation with bacterial cultures (mono-inoculation) in conditions of field experiments favors the increase of crop capacity of legume crops averagely by $12-15 \%$ [8]. For legume grasses inoculation, the preparation Rhizobophyte is used. The pre-sowing bacterization provides plants better development and formation of active nitrogen-fixing symbiosis [9]. In condition of Ukrainian forest 
steppe, it is expedient to conduct pre-sowing inoculation of bird's-foot trefoil seed with active strains of tuberous bacteria for their quantity- and nitrogen fixation activeness increase [10]. Dry mass growth on sites with seed bacterization in single-species crops of perennial legume grasses made $0,76-1,67 \mathrm{t} / \mathrm{ha}$, and in mixture with cereals $-0,46-1,10 \mathrm{t} / \mathrm{ha}$, respectively [11]. The nitrogen fixation activeness (mg nitrogen $/ \mathrm{m}^{2}$ per hour) in bird's-foot trefoil root zone makes 15,07, red clover - 9,07, alfalfa - 11,40 [12].

Among the basic biogenic elements, phosphorus plays a special role in plants mineral nutrition, performing primarily the functions of energetic balance regulator, as it is capable of forming compounds with a great supply of energy which is released in process of their hydrolysis [13]. In Carpathian region, the slightly soluble forms of phosphorous fertilizers (particularly calcium thermophosphate) are admissible to make "as in stock", whereas the majority of soluble fertilizers are expedient to connect with the period of plants' most physiological need in nutrition elements [14]. On poorly limed soils, the molybdenum fertilizers are effective, due to which the yield of legume-cereal herbage was increasing by 18-33\% [15]. Under bird's-foot trefoil, it is necessary to put phosphorous-potassium fertilizers combined with molybdenum ones, as they provide the most fodder mass and seeds crop capacity [16].

Research goal - to investigate the fertilization effect on dry matter collection dynamics and grass mix of bird's-foot trefoil and tymothy-grass fodder productivity.

Research methods. The researches were carried out at the department of plant growing and fodder production of Bukovinian state agricultural research station NAAS. The experimental plots' soil is a gray forest heavy-loamed medium-edged one $\left(\mathrm{pH}_{\text {сол }}-5,4\right.$; humus content $-1,84 \%$; easily hydrolyzed nitrogen - $84 \mathrm{mg} / \mathrm{kg}$; mobile forms of phosphates $\left(\mathrm{P}_{2} \mathrm{O}_{5}\right)-32 \mathrm{mg} / \mathrm{kg}$ (by Kirsanov); exchangeable potassium content $\left(\mathrm{K}_{2} \mathrm{O}\right)$ (by Maslova) - $145 \mathrm{mg} / \mathrm{kg}$ ). Carrying out the research, we were guided by Technique of conducting experiments on fodder production (A.O. Babych, 1994) [17]. On the day of sowing seed of bird's-foot trefoil, it was treated with Rhizobophyte (titer of bacterial cells in $1 \mathrm{~g}$ of the preparation not less than 3-4 mlrd) with expenditure rate $0,5 \mathrm{~L}$ of the preparation per $100 \mathrm{~kg}$ of seed. For fertilization, seed pre-sowing treatment with molybdenum ammonium $(50,0 \%$ a.s. (active substance) from the calculation $0,5 \mathrm{~kg} / 100 \mathrm{~kg}$ of seed was used.

Fodder chemical composition was determined at the Evaluation Department of quality, fodder safety and raw material at the Podillya Institute of fodder and agriculture NAAS. By the results of fodder chemical analysis, the calculation of fodder units quantity and exchangeable energy was carried out [18].

Research results. In the first year of using perennial herbs, bird's-foot trefoil seed treatment with Rhizobophyte and phosphorous fertilization significantly affected the legume-cereal herbage productivity. Thus, in the first slope, the increase from Rhizobophyte usage made 0,26 t/ha or $11 \%$, from phosphorous fertilization $-0,57$ t/ha or $24 \%$.

The maximum increase of dry matter output is obtained at compatible use of Rhizobophyte and phosphorous fertilizer $-0,87$ tha, or $37 \%$. On the background of applying $P_{60}$, combination of seed treatment with Rhizobophyte and molybdenum fertilizer caused even the reduce of dry matter output, comparing to using single Rhizobophyte (table 1).

Table 1. Dry matter output dynamics on timothy-grass - bird's-foot trefoil grass mix, depending on fertilization, $t / h a$

\begin{tabular}{|c|c|c|c|c|c|c|c|c|c|}
\hline \multirow{3}{*}{ Fertilization } & \multicolumn{9}{|c|}{ Years } \\
\hline & \multicolumn{3}{|c|}{2013} & \multicolumn{3}{|c|}{2014} & \multicolumn{3}{|c|}{2015} \\
\hline & -st slop & $\begin{array}{l}\text { 2-nd } \\
\text { slope }\end{array}$ & together & $\begin{array}{l}\text { 1-st } \\
\text { slope }\end{array}$ & $\begin{array}{l}\text { 2-nd } \\
\text { slope }\end{array}$ & together & -st slop & $\begin{array}{l}\text { 2-nd } \\
\text { slope }\end{array}$ & together \\
\hline Without fertilizers (control) & 2,37 & 4,41 & 6,78 & 4,81 & 2,66 & 7,47 & 4,53 & 1,88 & 6,41 \\
\hline Rhizobophyte & 2,63 & 4,68 & 7,31 & 5,38 & 2,17 & 7,55 & 4,62 & 1,87 & 6,49 \\
\hline$P_{60}$ & 2,94 & 5,42 & 8,36 & 5,56 & 2,83 & 8,39 & 4,99 & 2,02 & 7,01 \\
\hline Rhizobophyte $+P_{60}$ & 3,24 & 5,16 & 8,40 & 6,87 & 2,43 & 9,30 & 4,77 & 2,01 & 6,78 \\
\hline Rhizobophyte $+\mathrm{P}_{60}+$ Mo & 3,03 & 5,02 & 8,05 & 6,04 & 2,61 & 8,65 & 4,77 & 2,05 & 6,82 \\
\hline $\mathrm{HIP}(\mathrm{SSD})_{05}$, tha & 0,16 & 0,40 & & 0,24 & 0,19 & & 0,19 & 0,13 & \\
\hline
\end{tabular}


The use of fertilizers affected somewhat differently on perennial herbs productivity in the second slope. Thus, the dry matter increase from applying Rhizobophyte made 3,5\%, from phosphorous fertilization $\left(P_{60}\right)-22,9 \%$. That is, Rhizobophyte provided more effect in first slope. At the same time, in 2013 phosphorous fertilization provided practically equal dry mass in first and second slopes - 24 and $22,9 \%$. In total, for the two slopes, the most effective proved to be compatible use of phosphorous fertilizers and the biologic preparation based on nitrogen-fixing bacteria - rhizobophyte.

On the second year of using the herbage, the legume-cereal phytocenosis provided the highest dry matter output. Thus, in the first slope the perennial agro-phytocenosis productivity in unfertilized sites made 4,81 tha. On variant with birds-foot trefoil seed inoculation with Rhizobophyte, the dry matter growth to unfetilized herbages was 0,57 tha, or $11,9 \%$. The legume-cereal herbage nutrition with phosphorous fertilizer $\left(\mathrm{P}_{60}\right)$ provided the dry mass growth $0,75 \mathrm{t} / \mathrm{ha}$, or $15,6 \%$ comparing to unfertilized hayfield. Maximum dry matter collection (6,87 t/ha) in the first slope of 2014 was obtained on variant with Rhizobophyte seed treatment and phosphorous fertilization $\left(P_{60}\right)$, which provided the increase of dry matter output $2,06 \mathrm{t} / \mathrm{ha}$, or $42,8 \%$ compared to unfertilized control.

In the first slope in 2015 , only a tendency was notable to increase the dry matter collection on variant with Rhizobophyte usage. The most dry matter collection was obtained on variant with phosphorous fertilization $-4,99 \mathrm{t} / \mathrm{ha}$.

Hence, in the first three years of using legume-cereal herbage, the most favorable conditions for crop capacity formation were set on the variant with bird's-foot trefoil seed inoculation with Rhizobophyte and phosphorous fertilization $\left(P_{60}\right)$. Herewith, the highest bio-preparation effectiveness was observed in the first slope of the first two years of using the herbage. The combination of seed treatment with Rhizobophyte and molybdenum acid ammonium, at which even the reduce of dry matter output was observed, proved to be ineffective.

Averagely, for the first three years of using perennial herbs, the least productive proved to be the legume-cereal herbage without using fertilizers, where the dry matter output made $6,88 \mathrm{t} / \mathrm{ha}$, fodder units $-5,26 \mathrm{t} / \mathrm{ha}$, raw protein $-0,91 \mathrm{t} / \mathrm{ha}$ (Table 2 ).

Table 2. Fodder productivity of the grass mix of bird's-foot trefoil with tymothy-grass, depending on fertilization (averagely for 2013-2015)

\begin{tabular}{|c|c|c|c|c|}
\hline \multirow{2}{*}{ Fertilization } & \multicolumn{4}{|c|}{ Output from 1 ha } \\
\cline { 2 - 5 } & Dry matter, $\mathrm{t}$ & Fodder units, $\mathrm{t}$ & Raw protein, $\mathrm{t}$ & $\begin{array}{c}\text { Exchangeable } \\
\text { energy, } \mathrm{GJ}\end{array}$ \\
\hline Without fertilizers (control) & 6,88 & 5,26 & 0,91 & 60,26 \\
\hline Rhizobophyte & 7,12 & 5,52 & 1,06 & 62,19 \\
\hline $\mathrm{P}_{60}$ & 7,92 & 6,14 & 1,14 & 69,63 \\
\hline Rhizobophyte $+\mathrm{P}_{60}$ & 8,16 & 6,25 & 1,23 & 71,37 \\
\hline Rhizobophyte $+\mathrm{P}_{60}+\mathrm{Mo}$ & 7,84 & 6,09 & 1,18 & 68,70 \\
\hline
\end{tabular}

Also, on unfertilized sites, there was the least number of exchangeable energy accumulated with perennial herbs yield $-60,26 \mathrm{GJ} / \mathrm{ha}$.

Using fertilizers has significantly increased the fodder productivity of tymothy-grass and bird's-foot trefoil grass mix. Thus, bird's-foot trefoil seed inoculation with Rhizobophyte has favored the dry matter output increase by $0,24 \mathrm{t} / \mathrm{ha}$ or $3,5 \%$, fodder units - by $0,26 \mathrm{t} / \mathrm{ha}$ or $4,9 \%$, raw protein - on $0,15 \mathrm{t} / \mathrm{ha}$ or $16,5 \%$. That is, in our researches, using Rhizobophyte has mostly affected on raw protein output from one hectare. At phosphorous fertilization with calculation $\mathrm{P}_{60}$, the dry matter output has increased by 1,04 $\mathrm{t} / \mathrm{ha}$, fodder units - by $0,88 \mathrm{t} / \mathrm{ha}$, raw protein - by $0,23 \mathrm{t} / \mathrm{ha}$. The implementation of the bio-preparation Rhizobophyte on the background of phosphorous fertilization $\left(\mathrm{P}_{60}\right)$ has provided the dry matter output growth relating to unfertilized herbages by $1,28 \mathrm{t} / \mathrm{ha}$, or $19,7 \%$; fodder units - by $0,99 \mathrm{t} / \mathrm{ha}$, or $18,8 \%$; raw protein - by $0,32 \mathrm{t} / \mathrm{ha}$, or $35,2 \%$. Also, on the variant with phosphorous fertilization and seed treatment 
with Rhizobophyte, the number of exchangeable energy accumulated with the yield has increased by $71,37 \mathrm{GJ} / \mathrm{ha}$, which has exceeded on $18,4 \%$ the unfertilized variant indicator.

\section{Conclusions}

Averagely, for the first three years of using bird's-foot trefoil-cereal herbage, the best one by fodder productivity proved to be the variant with seed inoculation with Rhizobophyte and phosphorous fertilization $\left(P_{60}\right)$, on which 8,16 t/ha of dry matter was obtained, 6,25 t/ha of fodder units, 1,23 t/ha of dry protein and $71,37 \mathrm{GJ} / \mathrm{ha}$ of exchangeable energy accumulated with the yield.

\section{Bibliography}

1. Cherkasova V.A. (1976). Osvoenie sklonov pod pastbishcha i senokosy. [The development of slopes for pastures and hay]. Moskva: Kolos, 208 p. [In Russian].

2. Carlsson G., Huss-Danell K. (2003). Nitrogen fixation in perennial/forage legumes in the field. Plant and Soil. V. 253, Is. 2. P. $353-372$.

3. Ledgard S. (2001). Nitrogen cycling in low input legumebased agriculture, with emphasis on legume/grass pastures. Plant and Soil. V. 228, Is. 1. P. $43-59$.

4. Ledgard S., Steele K. (1992). Biological nitrogen fixation in mixed legume/grass pastures. Plant and Soil. V. 141 , Is. 1 - 2. P. $137-153$.

5. Patyka V.P., Petrychenko V.F. (2004). Mikrobna azotfiksatsiia u suchasnomu kormovyrobnytstvi. [Microbial nitrogen fixation in modern fodder production]. Kormy $i$ kormovyrobnytstvo. Vinnytsia: Vinnytsia. Vyp. 53. P. 3 - 11. [In Ukrainian].

6. Tyshchenko O.D., Andrusiva L.V. (2001). Reaktsiia sortiv liutserny na inokuliatsiiu shtamamy RNIZOBIUM MELILOTI. [Reaction of alfalfa varieties to inoculation by strains RNIZOBIUM MELILOTI]. Kormy i kormovyrobnytstvo. Kyiv: Ahrarna nauka. Vyp. 47. P. 49 - 50. [In Ukrainian].

7. Petrychenko V.F., Tykhonovych I.A., Kots S.la., Patyka M.V. (2012). Silskohospodarska mikrobiolohiia i zbalansovanyi rozvytok ahroekosystem. [Agricultural microbiology and balanced development of agroecosystems]. Visnyk ahrarnoi nauky. No 8. P. 5 - 11. [In Ukrainian].

8. Petrychenko V.F., Kots S.la. (2014). Symbiotychni systemy u suchasnomu silskohospodarskomu vyrobnytstvi. [Symbiotic systems in modern agricultural production]. Visnyk NANU. No 3. P. 57 - 66. [In Ukrainian].

9. Hrytsaienko Z.M., Ponomarenko S.P., Karpenko V.P., Leontiuk I.B. (2008). Biolohichno aktyvni rechovyny v roslynnytstvi. [Biologically active substances in crop production]. Kyiv: ZAT «Nichlava». 352 p. [In Ukrainian].

10. Kovtun K.P., Veklenko Yu.A., Bezvuhliak L.I. (2013). Vplyv udobrennia ta inokuliatsii na formuvannia botanichnoho skladu bobovo-zlakovoho travostoiu z liadventsem rohatym. [Effect of fertilization and inoculation on the formation of the botanical composition of bean-cereal grass with larva horn]. Kormy i kormovyrobnytstvo. Vinnytsia: TOV «Vydavnytstvo-drukarnia Dilo». Vyp.75. P. 155 - 160. [In Ukrainian].

11. Veklenko Yu.A., Kovtun K.P., Bezvuhliak L.I. et al. (2013). Ahroekolohichne obgruntuvannia adaptyvnykh resursooshchadnykh tekhnolohii stvorennia ta vykorystannia bahatorichnykh kormovykh ahrofitotsenoziv. [Agroecological substantiation of adaptive resource-saving technologies for the creation and use of perennial forage agrophytocenoses]. Visnyk ahrarnoi nauky. Spets. vyp. P. $78-83$. [In Ukrainian].

12. Volkohon V.V., Berdnikov O.M., Tsentylo L.V. (2013). Mikrobni preparaty. Osoblyvosti zastosuvannia u tekhnolohiiakh vyroshchuvannia silskohospodarskykh kultur. [Microbial drugs. Peculiarities of application in crop growing technologies]. Posibnyk ukrainskoho khliboroba. Naukovopraktychnyi zbirnyk «Zernobobovi ta bobovi kormovi kultury $v$ konteksti vidnovlennia ahrotsenoziv». Kyiv: TOV «Akadempres». T. 2. P. 44 - 73. [In Ukrainian].

13. Litvinov D.V. (2016). Dynamika vmistu rukhomoho fosforu $v$ chornozemi typovomu $v$ korotko rotatsiinykh sivozminakh. [Dynamics of the content of mobile phosphorus in chernozem typical in short 
rotation crop rotations]. Zbirnyk naukovykh prats NNTs «Instytut zemlerobstva NAAN». Kyiv: VP «Edelveis». Vyp. 2. P. 13 - 23. [In Ukrainian].

14. Topolnyi F.P., Lyshchuk S.S. (1993). Rezervy i zapasy fosforu $v$ gruntakh Ukrainskykh Karpat. [Reserves and reserves of phosphorus in the soils of the Ukrainian Carpathians]. Problemy ahropromyslovoho kompleksu Karpat: mizhvidom. tem. nauk. zb. Uzhhorod: UVVK «Patent». Vyp. 2. P. 50 - 58. [In Ukrainian].

15. Makarenko P.S., Demydas H.I., Koziar O.M. (2002). Lukivnytstvo. [Onion]. Kyiv: Nora-print. 394 p. [In Ukrainian].

16. Popova S.I., Kiryakova E.M., Yarmolenko E.N. (2010). Vliyanie pokrovnoy kul'tury, norm vyseva i mineral'nykh udobreniy na urozhaynost' kormovoy massy i semyan lyadventsa rogatogo. [The influence of the cover crop, seeding rates and mineral fertilizers on the yield of fodder and seed of horned bridle]. Innovatsionnomu razvitiyu APK - nauchnoe obespechenie: Sb. nauch. statey Mezhdunar. nauch.-prak. konf., posvyashchennoy 80-letiyu Permskoy gos. s.-kh. akademii im. ak. D.N. Pryanishnikova, g. Perm', 18 noyabrya 2010 g. Perm', 4. 2. P. 177 - 182. [In Russian].

17. Babych A.O. Ed. Metodyka provedennia doslidiv po kormovyrobnytstvu. [Methodology of experiments on fodder production]. (1994). Vinnytsia: Derzhavna kartohrafichna fabryka. 87 p. [In Ukrainian].

18. Vudmaska V.Iu., Prylutskyi P.P. (1975). Vyznachennia pozhyvnosti i yakosti kormiv u hospodarstvi. [Determination of nutrition and quality of feed at the farm]. Kyiv: Urozhai, 136 p. [In Ukrainian]. 